\title{
EUROINTEGRATION CRISIS AND ITS EFFECT ON UKRAINE'S FOREIGN POLICY AND SECURITY
}

\section{КРИЗА ЄВРОІНТЕГРАЦЇ̈ ТА Ї̈̈ ВПЛИВ НА ЗОВНІШНЮ ПОЛІТИКУ Й БЕЗПЕКУ УКРАЇНИ}

\section{КРИЗИС ЕВРОИНТЕГРАЦИИ И ЕГО ВОЗДЕЙСВИЕ ВНЕШНЮЮ ПОЛИТИКУ И БЕЗОПАСНОСТЬ УКРАИНЫ}

Yakovenko N.

Doctor of Science (History), Professor of the Institute of International Relations, Taras Shevchenko National University of Kyiv. E-mail: zaliznaledi@ukr.net

Piskorska G.

$\mathrm{PhD}$ (History), Senior Researcher of the Institute of International Relations, Taras Shevchenko National University of Kyiv. E-mail: piskorskagalina1 @gmail.com

Яковенко Н.Л.

Доктор історичних наук, професор, професор Інституту міжнародних відносин Київського національного університету імені Тараса Шевченка. E-mail: zaliznaledi@ukr.net

\section{Піскорська Г.А.}

Кандидат історичних наук, доцент, старший науковий співробітник Інституту міжнародних відносин Київського національного університету імені Тараса Шевченка. E-mail: piskorskagalina1 @ gmail.com

\section{Яковенко Н.Л.}

Доктор исторических наук, профессор, профессор Института международных отношений Киевского национального университета имени. Тараса Шевченко. E-mail: zaliznaledi@ ukr.net

\section{Пискорская Г.А.}

Кандидат исторических наук, доцент, старший научный сотрудник Института международных отношений Киевского национального университета имени Тараса Шевченко. E-mail: piskorskagalina1@gmail.com

Abstract. The article deals with the strategic approaches and interests of Ukraine in the context of the crisis of the European security system in connection with the RussianUkrainian conflict. Russian aggression against Ukraine from 2014, including the annexation of Crimea and deployment of a major war in Donbas, further aggressive and unpredictable actions of a large nuclear power have sharply increased instability of global security environment, greatly exacerbated the effect of negative factors aimed at destruction of the existing world order. Recent threats arise from the very nature of contemporary international relations and have become an objective phenomenon. The authors focuse on the causes of the current crisis of the European security system. The factors of formation and essence of the political position of the EU and NATO concerning the military-political aggression of Russia against Ukraine in 2014, are revealed. The peculiarities of the European security policy, strategic interests of the EU in conditions of the restoration of elements of block-civilization confrontation are analyzed. 
Key words: European security system, NATO, EU, Russia, Ukraine, military-political conflict, security strategies, security policy, defense component of the EU.

Анотація. У статті проаналізовано стратегічні підходи та інтереси Украйни в умовах кризи системи європейської безпеки у зв'язку з російсько-украӥнським конфліктом. Російська агресія проти Украӥни з 2014 року, включаючи анексію Криму та розгортання великої війни на Донбасі, подальші агресивні та непередбачувані дії великої ядерної енергетики різко посилили нестабільність глобальної середовища безпеки, значно загострили вплив негативних чинників, спрямованих на знищення існуючого світового порядку. Авторами акиентовано увагу на причинах сучасної кризи системи європейської безпеки. Виявлено чинники формування $i$ сутність політичної позиції ЄС та НАТО щуодо військово-політичної агресії Росії проти України у 2014 роиі. Проаналізовано особливості європейської політики у сфері безпеки, стратегічні інтереси ЄС в умовах відновлення елементів блоково-циивілізаційного протистояння. Зазначається, щзо Європейський Союз готовий посилювати оборонну співпращю щуодо подальшої інтеграчії військових можливостей і посилення взаємодї̈ з Північноатлантичним альянсом для досягнення ефективної взаємодії у подоланні нових загроз та розиирюючи сферу застосування політики сили. В статті визначаються важливі напрямки подальшого розвитку зовнішньополітичної і безпекової співпраці України з СС.

Ключові слова: система європейської безпеки, НАТО, ЄС, Росія, Украӥна, військово-політичний конфлікт, безпекові стратегї, безпекова політика, оборонний компонент $€ C$.

Аннотация. B статье анализируются стратегические подходы и интересь Украины в условиях кризиса системь европейской безопасности в связи с российскоукраинским конфликтом. Российская агрессия против Украины с 2014 года, включая аннексию Крыма и развертыввание крупной войны в Донбассе, дальнейшие агрессивные и непредсказуемые действия ядерной энергетики резко повысили угрозы глобальной безопасности, значительно усугубили влияние негативных факторов, направленных на уничтожение существующего мирового порядка. Авторы акцентируют внимание на причинах современного кризиса системы европейской безопасности. Определяются факторы формирования и сущцность политической позиции ЕС и НАТО относительно военно-политической агрессии России против Украины в 2014 г. Проанализировань особенности европейской политики в сфере безопасности, стратегические интересы EC в условиях обновления элементов блоково-цивилизачионного противостояния. Отмечается, что Европейский Союз готов усиливать оборонное сотрудничество по дальнейшей интеграџии военных возможностей и расширению взаимодействия с Североатлантическим альянсом для достижения эффективных результатов в преодолении новых угроз путем расширения сферы применения политики силь. В статье определяются важные направления дальнейшего развития внешнеполитического сотрудничества Украины с EC, а также их сотрудничества в области обеспечения безопасности.

Ключевые слова: система европейской безопасности, НАТО, ЕС, Россия, Украина, военно-политический конфликт, стратегии безопасности, политика безопасности, оборонный компонент ЄС.

Introduction. The Ukrainian crisis, mutual sanctions, and the results of the elections in the United States would suggest that states are gradually coming back to power politics. In conditions of confrontation between the powerful geopolitical players - the United States, NATO and the EU on the one hand, and on the other - the Russian Federation on the European continent and the vast Euro-Atlantic region of cooperation that arose with the beginning of Russian-Ukrainian conflict in 2014 , the European security system as well as the 
system of international relations in general, entered the period of obvious sharpening of the latent crisis. This situation is largely caused by miscalculations in the policies of «Western democracies». Among them, it should be noted, first of all, the failure of the European Union to reach consensus on the security policy of the subjects of integration and thus to act as a single center of international politics. For a long time, there was a lack of adequate strategy of European structures regarding the invariably aggressive foreign policy of the Russian Federation and its neglect of the basic norms of international law. Because of the growing challenges and threats to the European security system and the need for its reform in the context of the present renewal of elements of the block-civilizational confrontation, the peculiarities of the EU security policy should be analyzed.

Formulation of the problem. European integration processes have created a powerful core of gravity of dynamic, progressive development, which increasingly involve the EU's neighbors. The practice of the EU international relations has shown the aspiration of this supranational organization for such forms of interaction that predetermine the avoidance of force methods, but the Russian aggression against Ukraine from 2014, including annexation of Crimea and the start of a large-scale war in Donbas, further aggressive and unpredictable actions of the large nuclear power are causing problems for the European security system. By expanding the scope of its force policy, Russia consistently contributes to the growth of chaos in the international security environment, considering the increasing unpredictability on the international scene as a major instrument for increasing its own foreign policy influence.

The problem of formation of common European security and defense policy, taking into account the presence of numerous conflict factors in the world and in the European region in particular, has naturally been reflected in theoretical and applied research papers of foreign and domestic experts: conceptual approaches to the basic problems of European security are presented in the works of Zb. Brzezinski, B. Buzan, O. Vever, T. de Ville, J. Gau, J. Goodby, K. Deutsch, S. Key, G. Kennan, R. Cooper, S. Lynne-Jones, N. Maiers, J. Nye, D. Sidzhanski, D.A. Strauss, T. Wilborn, S. Walt, R. Ulman, T.L. Friedman, R. Holbrooke; the problem of strategic planning of common European security and defense policy was considered in the fundamental work of A. Dumulen, R. Mathew and G. Sarl; the correlation between the processes of EU enlargement and the establishment of security policy was analyzed in the papers of J. Delors, experts of R. Schumann Center for Security, Center for Security Studies, EU Institute for Strategic Studies, 'Our Europe' Center, Institute for Security Studies of Europe, International Institute for Peace Studies, etc.

The European security issues in contemporary political science are presented by the papers of such Ukrainian scholars as Ye. Kaminsky, M. Ozhevan, B. Parakhonsky, O. Litvinenko, A. Kudryachenko, V. Kopijka, V. Manzhola, O. Bodruk, A. Lipkan, L. Chekalenko, V. Golovchenko, G. Perepelytsya and others, the characteristic feature of which was the substantiation of Ukraine's integration into the European security system, based on objective circumstances and peculiarities of the development of Ukrainian state and the provision of national interests in the international background.

Among the publications dealing with the problems of the latest transformations of the system of international relations and European security (the period of the first decade of the XXI century) the works of Ukrainian scholars A. Martynov [15] T. Sidoruk [18], A. Grubinko [13] are of special interest as well as papers by foreign scholars E. Lucas, R. Cooper, S. Lehne [8], K. Nielsen [10].

It is also worth mentioning some new papers by foreign authors on the crisis of relations between Western institutions and Russia due to 2014 Russian-Ukrainian conflict (works by S. Erlanger [7], A. Sytas [12], L. Mangasarian [9], M. Pagano [11], B. Raitshooster [17]).

While analyzing European security processes, Ukrainian scholars in their research formulated ideas that significantly influenced on the formation of a conceptual vision of Ukraine's relations with the EU, in particular at the level of state power structures, in the form of political concepts and integration strategies into the Euro-Atlantic area. As it is noted in recent 
studies, the pragmatic approach to Ukraine's cooperation with the EU has been considerably increased, which involves taking into account various factors in shaping the foreign policy of the state. The Russian Federation's war against Ukraine in 2014 created a new situation that undoubtedly affected many aspects of relations between both actors of interstate cooperation [3].

The European Union Treaty not only established a mechanism for the formation of foreign and security policy, but also formulated main objectives of the European integration policy: protection of core values, interests and independence of the European Union; strengthening of the EU and its member states' security in all its forms; promotion of international co-operation; development and strengthening of democracy; respect for human rights and fundamental freedoms [4].

In order to achieve the stated goals within the framework of the EU foreign policy activities, mechanisms were used to coordinate and exchange information of common interest: developing a "common position" in perceiving and analyzing certain international events, harmonizing the positions of national governments with European political behavior in defining the goals and priorities of the EU concerning the third countries; the use of the armed forces by the European Union both autonomously and in common operations within the framework of NATO or the OSCE in case when diplomatic instruments are insufficient to ensure the security of the EU and its member states [5].

Accordingly, the European Council of the EU in Lisbon (1992) and in Brussels (1993) clearly defined the basic principles and conditions that could be used for joint actions and rapid reaction forces of the EU: the territorial proximity of the region to the conflict zone; strategic interests in the region or certain state; threats to the EU security interests. In particular, these principles concern those regions where the EU announced about its intentions to support the global peace process, primarily in Central and Eastern Europe, the former Yugoslavia, Russia, the Mediterranean and the Maghreb, the Middle East and South Africa. The problem of the EU role in the European security architecture is also conditioned by the position of the EU common foreign and security policy and the European defense policy; the attitude of the EU member states towards these political strategies; the ability of the EU after enlargement to propose a clear neighborhood policy with the border states, given that the modern European security architecture is evolving under the influence of external and internal factors of contemporary international system [14].

In the middle of the XX century Europe, as a part of Transatlantic Alliance, did not need additional security mechanisms, since, on the one hand, there was an American "nuclear umbrella" and NATO forces that were, and will continue to remain a key instrument for maintaining security in the European region in the event of a direct military threat or aggression; on the other hand, the UN and OSCE played a significant role in maintaining peace and stability in the world including the European region.

It is worth to mention subsequent delineation of functions and specification of forms and methods of interaction between the leading international organizations, whose activities include security and stability issues at many levels. The manifestation of this trend was a practical attempt to apply the distinction between NATO and the EU in the Balkans: NATO was reliant on purely military and military-political aspects of subregional security, while the EU was allotted police and humanitarian and political functions. Subsequently, political and economic strengthening of the EU led to creation of a purely European military-political potential, certain distancing of the latter from NATO and the accelerated development of common European security and defense policy [16].

In new constructive European situation, for the EU member states it became necessary to solve essentially new difficult problems related to ensuring their own protection from internal and external threats under the unpredictability of international processes, as well as rethinking the role of traditional European security institutions and allied relations with the United States, which was undergoing profound changes in the context of adopting a common European 
security and defense policy that can simultaneously cover all levels of security - from basic to highest ones, and also function on the brink of authority of international security institutions.

Controversy over the EU common foreign and security policy emerged during the Iraqi crisis (2003-2006), when French and British governments did not support the EU participation in Middle East peacekeeping operations; during the referenda on ratification of the EU Constitution, as among 25 EU member states only 15 ratified it; while agreeing on a common security policy that was to be approved by a consensus, rather than on a permanent international legal basis; during the riots in Egypt, Syria, and Libya, when the political positions of European countries differed in their decisions concerning internal conflicts regulation. Consensus on a common security policy remains the only EU-level security decision-making instrument that defines the principles and guidelines of strategy, joint actions, and at the same time it sometimes contradicts the positions and approaches of EU member states to specific regional and global situations [6].

Within its competence, the EU promotes the creation of rapid (operational) reaction forces to counter new challenges and threats, including terrorism, spread of high-tech weapons and weapons of mass destruction, regional conflicts, state failure, and organized crime. EU member states participated in peacekeeping operations in Congo, Afghanistan, Timor, Macedonia, Bosnia and Herzegovina, Iraq, Kosovo, Libya, and others. However, as showed the development of the system of international relations in Europe at the turn of XXXXI c., Western states made two major strategic mistakes in the post-bipolar period, which resulted in a situation when Europeans are unable to defend themselves from military aggression [Lehne, 2012: 4].

The first is that since the EU creation, the development of its defense resources, which are formally stipulated in the constituent treaties, has been slowed down. The union remained in traditional situation of strategic military-political and military-technological dependence on NATO and the United States. Deprived of strategic means of direct military influence, the European Union is suspended as an auxiliary organization for NATO with amorphous and limited functions of conflict prevention, police regulation in post-conflict areas and humanitarian assistance. NATO has retained the role of strength force in resolving military conflicts. The EU forces were actually deprived of their own operational command headquarters by including the EU Operational Planning Center into the structure of Headquarters of NATO's United Armed Forces in Europe. The EU states, due to the lack of material resources and conflicting international interests, cannot form an international center of strength within the structures of the community for its own operational protection. In its activities, the EU is dependent on political will and resources of the "big three" (Great Britain, France, Germany), whose share the military expenditures of the association makes up over $60 \%$. Thus nobody is ready for a full-scale war in Europe [8].

Starting from 2014, the uncontrolled flow of refugees to Europe, the growth of terrorist threat from IGIL and Russia's aggression against Ukraine urged on rethinking the issue of the EU security policy.

A vote on Brexit in the UK has also triggered the idea of revitalization of the EU defense component. After the British referendum, 27 member states agreed to launch a dialogue on the EU reform. As a result, on March 1, 2017, the European Commission presented the White Paper on the future of Europe, which described five possible scenarios for the development of the European Union till 2025 [20].

Among them: 1. to preserve the EU in its present form; 2. to concentrate exclusively on the single market; 3 . to allow countries that want greater integration, to interact more closely together in a number of areas; 4 . to focus on deeper integration in areas of common interest; 5 . to move on to deeper integration across all policy areas. Such a number of scenarios demonstrated that there was no single vision for the development of the organization. At the EU summit on March 25, Poland gave up signing a joint declaration, opposing the idea of multi-speed Europe, backed by Germany and France. In the end, the interpretations in the declaration were mitigated, but 
the basic idea was preserved. In the adopted document, states agreed that they would move at different rates and intensity, but would adhere to a unified policy.

During 2016-2017, the European Union implemented several steps aimed at deepening cooperation within the framework of common European security and defense policy.

A Global Strategy for the European Union's Foreign and Security Policy adopted in June 2016 "Shared Vision, Common Action: A Stronger Europe" offers a new vision of the global role of the European Union and emphasizes the readiness of the organization to guarantee peace and security of its borders and citizens. In the Foreword to the EU Global Strategy, the EU High Representative Federika Mogherini stressed that our whole region has become less secure and less protected [1]. That is why the Global Strategy raises security-defense issues to the highest level of the EU attention - the level of heads of states. The creation of the EU Military Planning Conduct and Capability Facility was a milestone in the implementation of the EU Global Strategy. Though it is not a classical full-fledged military headquarters, it will be responsible for EU military operations.

The Global Strategy emphasizes that the EU must achieve its own strategic autonomy. And this is possible only if the EU creates its own European army. However, the representatives of the European Union do not have a common understanding of how such a structure will function. In their view, the formation of the "European Army" creates risks of splitting the transatlantic unity, because not all EU countries support this idea, and it is extremely difficult to draw a line between the EU-NATO defense and security powers. As it was noted, in the EU, the forces of rapid (operational) reaction are already operating - battle tactical groups (Battlegroup), which today still have limited capabilities and are mainly peacekeepers. Since the EU does not have a clear intention to create its own army, cooperation between the EU and NATO, as foreseen by the Global Strategy, has intensified. For the European Union, the Alliance remains a pillar in Europe in terms of confronting military threats, since no EU member state has sufficient military capabilities. The EUNATO Joint Declaration, signed in June 2016, identified the directions for this cooperation, which were detailed in the package of EU proposals in December 2016.

EU countries are to reconsider their national defense expenditure. The process of implementation of the EU Global Strategy was influenced by the UK decision to leave the the EU, because it makes Brussels review many things, for example, the cost of defense needs. To date, only four EU member states spend at least $2 \%$ of their GDP on defense needs. During the NATO summit in Warsaw (2016), a joint declaration on cooperation was signed by the EU and NATO, according to which the North Atlantic Alliance will remain the cornerstone of European security, while cooperation between the two organizations to combat hybrid threats, defense capabilities, cyber security and other issues will deepen [2].

The action plan proposed by the European Commission in November 2016 foresees the creation of a European Defense Fund to support investments in joint research and development of defense equipment and technologies that should address the problem of duplication of military production in the EU member states. The size of this fund can be 5-6 billion euros per year.

On June 22, 2017, at the meeting of the Council of the EU, Heads of the EU states approved the Permanent Structured Cooperation (PESCO) plan of the member states, in military-political sphere. Summit participants also agreed on the creation of a single fund to finance the development of weapons systems and their joint procurement. At the meeting, it was stressed that strengthening the military cooperation would not allow the EU to compete with NATO, but would increase its ability to carry out its own large-scale operations, in which, besides the armed forces, diplomacy and assistance for the development of other countries would be used. In the context of growing international tensions at its borders, the European Union is ready to step up defense cooperation to further integrate military capabilities and improve its interaction with the North Atlantic Alliance to achieve effective cooperation in overcoming new threats. 
Security problems in Ukraine-EU relations became extremely important when Ukraine appeared in a situation of a dividing line along its western border. In fact, the events in Ukraine caused another split between the EU states, this time according to the level of loyalty to Russia's policy. The anti-Russian group includes Britain, Sweden, and above all the Baltic states, Poland and Romania. The latter are a potential target of Russian aggression. Austria, Finland, Hungary and Slovakia are against the introduction of sanctions. The EU Common Security Strategy on Ukraine has declared principles of cooperation to ensure stability and security on the European continent. In the context of EU enlargement, it was about recognition of Ukraine as a sphere of common important interests of EU member states; and the relationship between Ukraine and the EU as a strategic and unique partnership.

According to conclusions of the round table discussion on "The EU Global Strategy: Place, Role and Contribution of Ukraine", held in 2017 with the support of Conrad Adenauer Foundation in Ukraine, Ukraine's primary contribution to Europe's security is to strengthen its own defense capabilities and deter Russian aggression at its eastern borders. Taking into account the factors of Ukraine's geographical location, its understanding of the situation in Eastern Europe, the experience gained in confronting Russian aggression, and mechanisms to counter hybrid threats, in the future Ukraine could be included in the formats of EU foreign policy and security activities, participate in EU missions and operations, as it is now done, for example, by Switzerland and Norway [19].

Ukraine is an important partner of the EU in the east of Europe. Ukraine is mentioned in the section on "European Security System" in the context of counteraction to Russia's aggression, which confirms its key importance for EU security and determines the prospects of such a dimension of cooperation. According to expert V. Martynyuk, a small number of references concerning Ukraine in the EU Global Strategy in comparison with the countries of the Middle East and the Sahel shows that the EU regards Ukraine not as a source of threats but as a partner in creating a security environment in Eastern Europe. Expert A. Najos noted that Ukraine, despite the war that has been lasting for the fourth year, did not become an EU source of illegal migration and refugees, in contrast to Syria, since during three years of the war, only about 500 Ukrainians have requested asylum in neighboring Poland, although in Ukraine itself there are about 1.8 million internally displaced persons. The security of Ukraine and EU security, as noted by M. Masarikova, are closely interconnected.

Majority of Ukrainian experts positively assessed the degree of Ukraine's integration into the EU Common Foreign and Security Policy: $46.9 \%$ consider it to be satisfactory and sufficient; $18.8 \%$ - that it corresponds actual opportunities of Ukraine and the EU. The best contribution to European security is the deterrence of Russian aggression in the East by the Ukrainian Army [19].

The European Union recognizes that today Russia is a major strategic challenge, as it annexed Crimea and strengthened its military presence in the region. In particular, the Global Strategy stated that Russia's violation of international Law and destabilization of Ukraine as the top of prolonged conflicts in the Black Sea region have called into question the European security order on its very basis. Therefore, the priority objectives of security cooperation between Ukraine and the EU are recognized the expansion of the format of military-political dialogue, assistance in professional training of Ukrainian military, joint military exercises and participation in peacekeeping operations, etc. [1].

Ukrainian experts identified energy security (17.5\%) and information security $(16.2 \%)$ as important directions for further development of Ukraine's foreign and security cooperation with the EU. The second group of priority spheres includes the following: military cooperation and participation in EU operations (12.5\%); counteracting illegal migration (10\%); cyber security $(8.7 \%)$; counteraction to hybrid aggression $(7.5 \%)$. The third-rate group consists of: reforming the security sector (5\%); military and technical cooperation (MTC) (5\%); fight against terrorism $(5 \%)$. And the least important directions of Ukraine-EU cooperation development mentioned by the experts were: ecological security; fight against organized crime; science and education; fight against corruption; social security; cooperation in other regions; sustainability. 
The Ukrainian context of cooperation with the EU in the field of information security is due to realities of the hybrid war, lack of effective protection against negative external information influence. After all, the Russian Federation has one of the largest and most powerful media potential in the world, especially in the field of broadcasting [21]. It should be noted that the primary objects of the Russian operation in Crimea at the end of 2013 - beginning of 2014 were Television and telecommunication networks.

The European Union has also undergone a powerful informational attack, carried out by the RF in recent years and from the stage of "denial of the problem", the EU is passing to its "adoption". It is expressed, in particular, in the adoption of the "Common principles of combating hybrid threats - the response of the European Union", the refusal of part of Russian propaganda resources in European countries, and so on [22].

Therefore, in the cooperation of Ukraine with the EU, the information component becomes more important and at the same time it becomes one of the elements of ensuring national security, since the use of information technologies determines the structure and quality of weapons, the protection of information resources (electronic networks, banks and databases, etc.) from unauthorized access or destruction, development and implementation of appropriate means of protection; creation of information security system. Ukraine can share with the EU its results concerning timely identification of Russia's preparation and conduct information campaigns and the definition of effective countermeasures.

The course towards European integration occurs from the very nature of Ukraine's state independence, its desire to become an integral part of the European family of nations. The European choice is the movement of Ukraine towards real democracy, information society, socially oriented market economy based on the rule of law and safeguarding of human rights and freedoms.

That is why for Ukraine, European integration must remain a strategic priority of foreign policy, but we should realize that at the present stage the European Union cannot fully guarantee Ukraine's national security. We can rely only on political, diplomatic, informational, financial and economic support from the European Union, as well as on its promotion of necessary reforms for Ukraine in all spheres of public life.

Conclusions. Recent threats arise from the very nature of contemporary international relations and have become an objective phenomenon. In view of this, the national level of security assurance is not enough to prevent and overcome them. Overcoming these threats, considering their transnational nature, requires global efforts of the world community. Along with the need to find collective forms of security assurance at the global and regional levels, the modern world puts shared responsibility on all its actors. Ignoring negative and threatening trends that emerge in some part of the world, sooner or later, but inevitably causes them to spread and reach the far-away countries. Recent years have proved to be critical to international security. Russian aggression against Ukraine from 2014, including the annexation of Crimea and deployment of a major war in Donbas, further aggressive and unpredictable actions of a large nuclear power have sharply increased instability of the global security environment, greatly exacerbated the effect of negative factors aimed at destruction of the existing world order.

\section{References}

1. Shared Vision, Common Action: A Stronger Europe. A Global Strategy for the European Union's Foreign And Security Policy. https://europa.eu/globalstrategy/sites/globalstrategy/files/eugs_review_web.pdf

2. Warsaw Summit Communiqué .Issued by the Heads of State and Government participating in the meeting of the North Atlantic Council in Warsaw 8-9 July 2016, https://www.nato.int/cps/uk/natohq/official_texts_133169.htm

3. Аналітична доповідь до Щорічного Послання Президента України до Верховної Ради України «Про внутрішне та зовнішнє становище України в 2017 році» 
[Analytical Report on Yearly Address of the President of Ukraine to the Supreme Rada of Ukraine "On Internal and External Position of Ukraine in 2017], <http://www.niss.gov.ua/public/File/book_2017/Poslanya_druk_fin.pdf>

4. Європейська політика безпеки та оборони (довідка). [Електроний документ]. [European Security and Defence Policy], <http://www.mil.gov.ua/index.php?lang=ua\&part=euintegration\&Hub =evrop_polit>

5. Конституційні акти Європейського Союзу (в редакції Лісабонського договору). (2010) [Constitutional Acts of the European Union (in the wording of the Lisbon Treaty)]. Київ : К.І.С.

6. Стратегічна концепція оборони та безпеки членів Організації Північноатлантичного договору, прийнята главами держав та урядів у Лісабоні 19 листопада 2010 p. [Strategic Concept of Defense and Security of the Members of the North Atlantic Treaty Organization, adopted by Heads of State and Government in Lisbon on November 19, 2010], <http://www.nato.int/cps/uk/SID-1EF4FB13EAB6DA59/natolive/official>

7. Erlanger S. (2014) 'Eastern Europe Frets About NATO's Ability to Curb Russia', The New York Times April 23.

8. Lehne S. (2012) 'The Big Three in EU Foreign Policy', The Carnegie Papers July: 38.

9. Mangasarian L. (2014) 'Putin Emboldened on Instability Arc by EU Defense Divide', < http://www.bloomberg.com>

10. Nielsen K. L. (2013) 'EU Soft Power and the Capability-Expectations Gap', Journal of Contemporary European Research 9 (5): 723-739.

11. Pagano M. (2014) 'Land for gas: Merkel and Putin discussed secret deal could end Ukraine crisis', The Independent 31 July, 〈http://www.independent.co.uk>

12. Sytas A., Croft A. (2014) 'Insight - Ukraine crisis will be «game changer» for NATO', Gaiziunai, Lithuania / Brussels, <http://in.reuters.com>

13. Грубінко $A$. 'Криза системи європейської безпеки в умовах російсько-українського конфлікту: Стратегічні підходи та інтереси Великої Британії' ['The crisis of the European security system in the Russian-Ukrainian conflict: the strategic approaches and interests of the United Kingdom'], <shron1.chtyvo.org.ua/Hrubinko_Andrii/Kryza_systemy_ievropeiskoi_bezpeky_v_umova kh_rosiisko-ukrainskoho_konfliktu_stratehichni_pidkhody_ta.pdf>

14. Литвиненко О. В., Горбулін B. (2009) 'Європейська безпека: можливий шлях послабити виклики і загрози' ['European security: a possible way to ease challenges and threats'], Dzerkalo Tyzhnya 43: 7.

15. Мартинов А. Ю. (2009) Спільна зовнішня та оборонна політика Європейського Союзу (90-mi pp. XX cm. - 10-ті рр. XXI cm.). Погляд з Украӥни [Common Foreign and Security Policy of the European Union (1990-s - 2010-s): view from Ukraine]. Київ : Інститут історії України НАН.

16. Полтораков О. Ю. (2009) Безпека держави та безпека суспільства : специфіка політичного взаємовпливу в наиіональному та європейському контекстах [State security and public safety: the specifics of political interactions in the national and European contexts]. Київ : Вид-во «LAT \& K».

17. Райтиустер Б. (2015) Путінократія. Людина влади та ї̈ система [Putinocracy. Man of power and his system]. Харків : Віват.

18. Сидорук T. В. (2014) 'Геополітичний вимір міжнародних процесів у Східній Свропі: СС та Росія у регіоні «спільного сусідства' ['Geopolitical dimension of international processes in Eastern Europe: EU and Russia in the region of "common neighborhood'], Hilea, scientific journal 81: 352-357.

19. Глобальна стратегія СС. Місце, роль і внесок України [EU Global Strategy. Place, role and contribution of Ukraine]. Центр глобалістики «Стратегія XXI», <http://www.ji-magazine.lviv.ua/2017/Global_strategiya_EC.htm> 
20. Европейская Комиссия представила доклад о будущем Европы: Пути сохранения единства в рамках Союза 27 стран [The European Commission presented a report on the future of Europe: Ways to preserve unity within the Union of 27 countries], https://eeas.europa.eu/headquarters/headquarters-homepage_ru/22040/

21. "Гібридна" війна Росії - виклик і загроза для Європи ['Hybrid' war of Russia challenge and threat for Europe], <http://old.razumkov.org.ua/ukr/upload/GIBRIDWAR-FINAL-1-1.pdf>

22. Joint Framework on countering hybrid threats - a European Union response: Joint communication to the European Parliament and the Council, JOIN (2016) 18 final, <http://ec.europa.eu/DocsRoom/documents/16201> 